Check for updates

Cite this: RSC Adv., 2019, 9, 34652

Received 13th October 2019 Accepted 23rd October 2019

DOI: $10.1039 / c 9 r a 08345 f$

rsc.li/rsc-advances

\section{A chemosensor with a paddle structure based on a BODIPY chromophore for sequential recognition of $\mathrm{Cu}^{2+}$ and $\mathrm{HSO}_{3}{ }^{-} \uparrow$}

\author{
Shengling $\mathrm{Li}^{\text {a }}$ Duanlin $\mathrm{CaO},{ }^{a}$ Zhiyong $\mathrm{Hu}^{\text {ab }}$ Zhichun $\mathrm{Li}{ }^{a}$ Xianjiao Meng, ${ }^{a}$ \\ Xinghua $\mathrm{Han}^{\mathrm{ab}}$ and Wenbing $\mathrm{Ma}$ (iD *ab
}

\begin{abstract}
In this study, a highly selective chemosensor $\mathrm{ML}$ based on a BODIPY fluorescent chromophore was synthesized for sequential recognition of $\mathrm{Cu}^{2+}$ and $\mathrm{HSO}_{3}{ }^{-}$in a $\mathrm{CH}_{3} \mathrm{OH} / \mathrm{H}_{2} \mathrm{O}(99: 1 \mathrm{v} / \mathrm{v})$ system, which contained three recognition sites and its structure characterized by ${ }^{1} \mathrm{H} N M R,{ }^{13} \mathrm{C} N M R$ and ESI-HR-MS. The sensor ML showed an obvious "on-off" fluorescence quenching response toward $\mathrm{Cu}^{2+}$ and the ML$\mathrm{Cu}^{2+}$ complex showed an "off-on" fluorescence enhancement response toward $\mathrm{HSO}_{3}{ }^{-}$. The detection limit of the sensor $\mathrm{ML}$ was $0.36 \mu \mathrm{M}$ to $\mathrm{Cu}^{2+}$ and $1.4 \mu \mathrm{M}$ to $\mathrm{HSO}_{3}^{-}$. In addition, the sensor $\mathrm{ML}$ showed a 1:3 binding stoichiometry to $\mathrm{Cu}^{2+}$ and the recovery rate of $\mathrm{ML}-\mathrm{Cu}^{2+}$ complex identifying $\mathrm{HSO}_{3}{ }^{-}$ could be over $70 \%$. Sensor ML showed remarkable detection ability in a pH range of 4-8.
\end{abstract}

\section{Introduction}

Copper is an essential trace element for organisms and plays an important role in various biological processes such as catalysis of enzymes, gene expression and protein synthesis. ${ }^{1-5}$ Under normal conditions, the allowable limit of $\mathrm{Cu}^{2+}$ is $15.7-23.6 \mu \mathrm{M}$ in blood and $20-30 \mu \mathrm{M}$ in drinking water, respectively. ${ }^{6,7} \mathrm{~A}$ moderate concentration of $\mathrm{Cu}^{2+}$ is helpful to maintain the normal function of the body, but an excess concentration of $\mathrm{Cu}^{2+}$ may cause many neurological complications such as Wilson's disease and Alzheimer's disease. ${ }^{8-11}$ Therefore, it is imperative to develop a simple, rapid and sensitive analytical method for detecting $\mathrm{Cu}^{2+}$. Some fluorescent sensors can identify metal ions selectively and colorimetrically ${ }^{12,13}$ and have many advantages such as high selectivity and sensitivity, simple operation and low cost, making them attractive in the detection of $\mathrm{Cu}^{2+} \cdot{ }^{14-19}$

$\mathrm{SO}_{2}$ is the main component of acid rain as it can be dissolved in neutral aqueous solution to form a mixed system with a $\mathrm{HSO}_{3}{ }^{-}$to $\mathrm{SO}_{3}{ }^{2-}$ molar ratio of about $3: 1 .^{20-23} \mathrm{HSO}_{3}{ }^{-}$plays an important role in both enzymatic and non-enzymatic reactions, and it is widely used as preservatives in foods and beverages. ${ }^{24,25}$ However, excessive intake of $\mathrm{HSO}_{3}{ }^{-}$can not only cause damage to tissues, cells and biological macromolecules, but also can cause respiratory disease and many neurological disorders. ${ }^{26-28}$ The acceptable daily intake of $\mathrm{HSO}_{3}{ }^{-}$should be less than $0.7 \mathrm{mg}$

${ }^{a}$ School of Chemical Engineering and Technology, North University of China, Taiyuan 030051, P. R. China. E-mail: mawenbing@nuc.edu.cn

${ }^{b}$ National Demonstration Center for Experimental Comprehenisve Chemical Engineering Education, North University of China, Taiyuan 030051, P. R. China

$\dagger$ Electronic supplementary information (ESI) available. See DOI: 10.1039/c9ra08345f $\mathrm{kg}^{-1}$ of body weight ${ }^{29}$ and the sulfite content in foods and beverages should be less than $125 \mu \mathrm{M}^{24}$ In recent years, fluorescent sensors have been developed using different approaches for detecting $\mathrm{HSO}_{3}{ }^{-}$, such as coordination to metal ions, ${ }^{30}$ selective reaction with aldehyde, ${ }^{31,32}$ selective deprotection of levulinate group ${ }^{33,34}$ and Michael-type addition. ${ }^{35-37}$ However, there are few reports on the development of chemical sensors that can sequentially identify metal ions and $\mathrm{HSO}_{3}{ }^{-}$ and simultaneously avoid interference by other sulfurcontaining compounds. Clearly, it is more efficient and cost effective to sequentially identify metal ions and anions in practical applications.

BODIPY fluorescent dye is often used as a chromophore for the design and synthesis of fluorescent sensors because of its high molar extinction coefficient, high fluorescence quantum yield, good photothermal stability, easy structural modification and adjustable absorption and emission wavelengths to the infrared visible region..$^{38-42}$ In this study, we synthesized a chemosensor ML with a paddle structure ${ }^{\mathbf{4 3 , 4 4}}$ and three metal ion recognition sites by introducing three BODIPY fluorescent chromophores. This sensor showed an "on-off-on" fluorescence response to $\mathrm{Cu}^{2+}$ and $\mathrm{HSO}_{3}{ }^{-}$in $\mathrm{CH}_{3} \mathrm{OH} / \mathrm{H}_{2} \mathrm{O}(99: 1 \mathrm{v} / \mathrm{v})$ system. Importantly, the colour of the test solution changed obviously, indicating that the sensor ML could be used for naked eye detection of $\mathrm{Cu}^{2+}$ and $\mathrm{HSO}_{3}{ }^{-}$(Scheme 1).

\section{Experimental}

\section{Materials and methods}

Compound $\mathbf{1}$ and $\mathbf{2}$ were synthesized as described in previous studies. ${ }^{45,46}$ Other solvents and starting materials were purchased from Aladdin and Energy Chemical Reagents Ltd. 


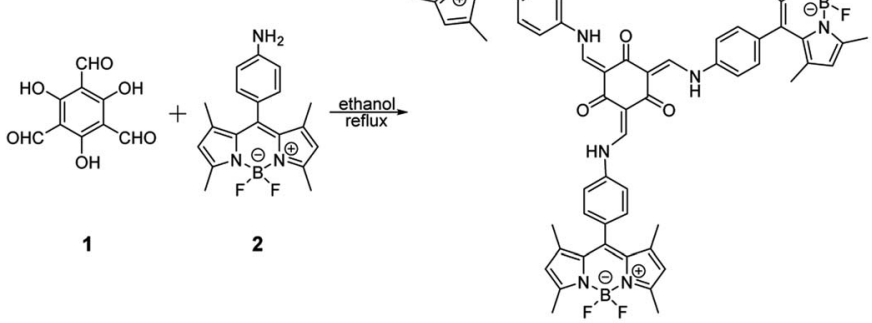

ML

Scheme 1 Synthesis of sensor molecule ML.

Ultrapure water was used through all the tests. The $\mathrm{pH}$ of all solutions was adjusted on a PHS-3C pH meter (Shanghai, China). The ${ }^{1} \mathrm{H}$ NMR (400 M) and ${ }^{13} \mathrm{C}$ NMR $(100 \mathrm{M})$ spectra were recorded on a spectrometer (Switzerland) in $\mathrm{CDCl}_{3}-d$ and DMSO- $d_{6}$ solutions. The SEI-MS spectra of sensor ML was recorded on a Bruker Solarix XR Fourier transform-ion cyclotron resonance (FT-ICR) mass spectrometer. The UV-spectras of all samples were recorded on a UV-2602 spectrophotometer (Shanghai, China), and all fluorescence spectras were recorded on a Hitachi F-2500 spectrophotometer (Japan).

\section{Synthesis}

Preparation of sensor ML. A $50 \mathrm{~mL}$ round-bottomed flask containing compound $1(0.2 \mathrm{mmol}, 42 \mathrm{mg})$, compound 2 (0.62 mmol, $210 \mathrm{mg}), 20 \mathrm{~mL}$ absolute ethanol and a drop of glacial acetic acid was heated to reflux for $12 \mathrm{~h}$ and TLC monitoring. The mixture was cooled to room temperature, filtered, and washed with ice ethanol, and the filter cake was purified by silica gel column chromatography (petroleum ether: ethyl acetate $=5: 1-1: 1)$ to afford an orange solid $(172 \mathrm{mg}, 73 \%) .{ }^{1} \mathrm{H}$ NMR ( $\left.\mathrm{CDCl}_{3}-d, 400 \mathrm{MHz}, \mathrm{TMS}\right): \delta(\mathrm{ppm})$ 13.45-13.53 (m, 2H), 13.10-13.14 (m, 1H), 8.81-8.92 (m, 3H), 7.45-7.50 (m, 6H), 7.35$7.40(\mathrm{~m}, 6 \mathrm{H}), 6.01(\mathrm{~s}, 6 \mathrm{H}), 2.57(\mathrm{~s}, 18 \mathrm{H}), 1.46(\mathrm{~s}, 18 \mathrm{H}) .{ }^{13} \mathrm{C} \mathrm{NMR}$ ( $\left.\mathrm{CDCl}_{3}-d, 100 \mathrm{MHz}, \mathrm{TMS}\right): \delta$ (ppm): 185.5, 155.9, 149.2, 142.8, 140.2, 139.7, 132.4, 131.4, 130.0, 121.5, 118.3, 107.2, 14.7, 14.6. The NMR spectra of sensor ML were shown in Fig. S1 and S2. $\dagger$ HRMS (ESI): $m / z$ calcd for $\mathrm{C}_{66} \mathrm{H}_{61} \mathrm{~B}_{3} \mathrm{~F}_{6} \mathrm{~N}_{9} \mathrm{O}_{3}\left[(\mathrm{M}+\mathrm{H})^{+}\right]: 1174.5083$, found 1174.5103 (Fig. S3†).

\section{General procedure for fluorescence spectra experiments}

In this study, sixteen kinds of metal cations and thirteen kinds of anions were selected. Cations included: $\mathrm{K}^{+}, \mathrm{Ca}^{2+}, \mathrm{Na}^{+}, \mathrm{Li}^{+}, \mathrm{Mg}^{2+}$, $\mathrm{Zn}^{2+}, \mathrm{Fe}^{3+}, \mathrm{Cu}^{2+}, \mathrm{Al}^{3+}, \mathrm{Ag}^{+}, \mathrm{Hg}^{2+}, \mathrm{Cs}^{+}, \mathrm{Pb}^{2+}, \mathrm{Cd}^{2+}, \mathrm{Ba}^{2+}$ and $\mathrm{Ni}^{2+}$; anions included: $\mathrm{F}^{-}, \mathrm{Cl}^{-}, \mathrm{Br}^{-}, \mathrm{I}^{-}, \mathrm{OAc}^{-}, \mathrm{HCO}_{3}{ }^{-}, \mathrm{CO}_{3}{ }^{2-}, \mathrm{HSO}_{3}{ }^{-}$, $\mathrm{SO}_{3}{ }^{2-}, \mathrm{SO}_{4}{ }^{2-}, \mathrm{S}^{2-}, \mathrm{NO}_{3}{ }^{-}$and $\mathrm{NO}_{2}{ }^{-}$. All tests were carried out at room temperature $\left(25^{\circ} \mathrm{C}\right)$ in $\mathrm{CH}_{3} \mathrm{OH} / \mathrm{H}_{2} \mathrm{O}(99: 1 \mathrm{v} / \mathrm{v})$ system. The UV-vis absorption spectra and fluorescence spectra of sensor $\mathbf{M L}$ at a concentration of $5 \times 10^{-6} \mathrm{M}$ were recorded and the excitation wavelength was $475 \mathrm{~nm}$, the slits of emission and excitation were $5 \mathrm{~nm}$ in all experiments. The stock solutions of various metal ions and anions $\left(1 \times 10^{-2} \mathrm{M}\right)$ were prepared from chlorine and sodium salts in ultrapure water, respectively.

\section{Results and discussion}

\section{UV and fluorescence response of sensor ML towards $\mathrm{Cu}^{2+}$}

The UV-vis spectra of sensor ML and 10 equiv. different metal ions responses were shown in Fig. 1. The sensor ML showed no response to metal ions except $\mathrm{Cu}^{2+}$. The maximum absorption wavelength showed a significant red shift from $499 \mathrm{~nm}$ to $510 \mathrm{~nm}$ with a red shift of $11 \mathrm{~nm}$, and the absorbance was also significantly reduced. The color of the solution changed from yellow to pink, indicating that the sensor ML could be used for naked eye recognition of $\mathrm{Cu}^{2+}$.

Fig. 2 showed that as the $\mathrm{Cu}^{2+}$ concentration increased, the absorbance decreased gradually and the absorption peak became wider. The maximum absorption wavelength shifted from $499 \mathrm{~nm}$ to $510 \mathrm{~nm}$, and the color of the solution changed gradually from yellow to pink. The sensor ML coordinated with $\mathrm{Cu}^{2+}$ to form a stable complex, resulting in a decrease in the intensity of its UV-vis spectrum and a red shift. The five equal concentration points were observed at $339 \mathrm{~nm}, 378 \mathrm{~nm}, 444 \mathrm{~nm}$,

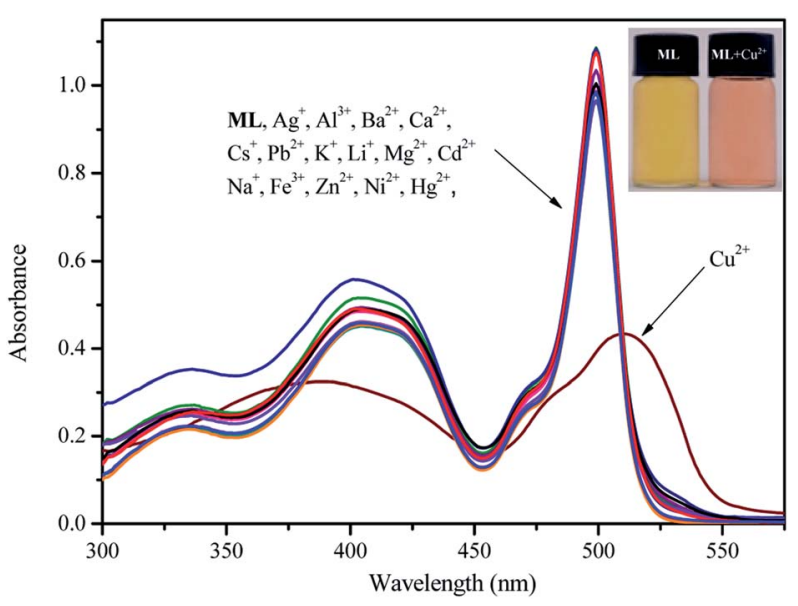

Fig. 1 UV-vis spectra of sensor $\mathrm{ML}$ in $\mathrm{CH}_{3} \mathrm{OH} / \mathrm{H}_{2} \mathrm{O}(99: 1 \mathrm{v} / \mathrm{v})$ system with the addition of 10 equiv. of metal ions and blank.

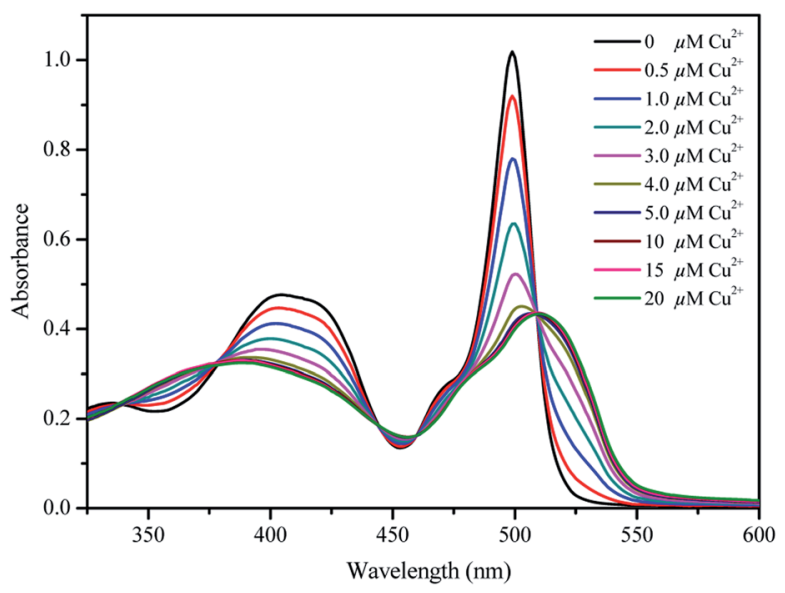

Fig. $2 U V$-vis spectra of sensor $M L$ of various concentrations [0 $\mu \mathrm{M}$, $0.5 \mu \mathrm{M}, 1.0 \mu \mathrm{M}, 2.0 \mu \mathrm{M}, 3.0 \mu \mathrm{M}, 4.0 \mu \mathrm{M}, 5.0 \mu \mathrm{M}, 10 \mu \mathrm{M}, 15 \mu \mathrm{M}, 20 \mu \mathrm{M}$ $\mathrm{Cu}^{2+}$ ] in $\mathrm{CH}_{3} \mathrm{OH} / \mathrm{H}_{2} \mathrm{O}(99: 1 \mathrm{v} / \mathrm{v})$ system. 


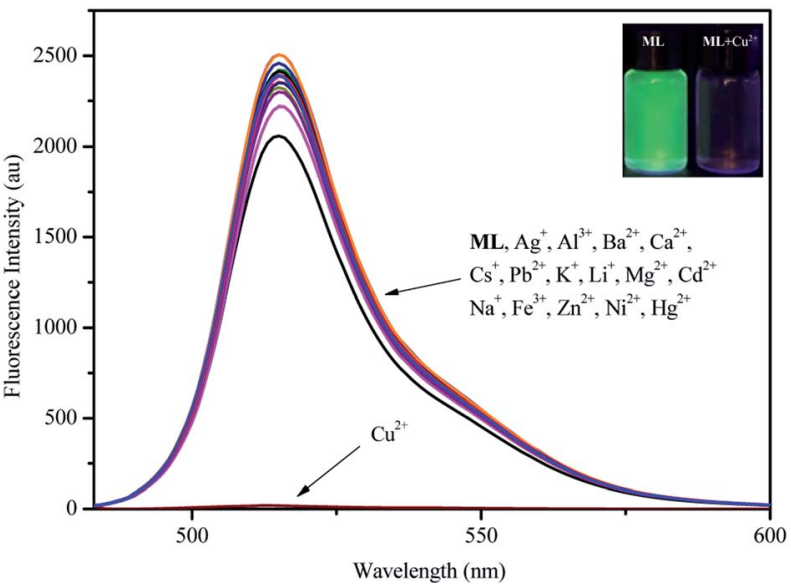

Fig. 3 Fluorescence spectra of sensor $\mathrm{ML}$ in $\mathrm{CH}_{3} \mathrm{OH} / \mathrm{H}_{2} \mathrm{O}(99: 1 \mathrm{v} / \mathrm{v})$ system at an excitation of $475 \mathrm{~nm}$ with the addition of 10 equiv. of metal ions and blank.

$460 \mathrm{~nm}$ and $509 \mathrm{~nm}$, respectively, indicating that the sensor ML and the complex $\mathbf{M L}-\mathrm{Cu}^{2+}$ were in a dynamic equilibrium.

Fig. 3 showed that the addition of $\mathrm{Cu}^{2+}$ resulted in almost complete quenching of the fluorescence intensity of the sensor ML, but only a slight change in the fluorescence intensity of other metal ions. The maximum emission wavelength was $515 \mathrm{~nm}$ and the Stokes shift was $40 \mathrm{~nm}$, and thus the sensor ML showed good selectivity to $\mathrm{Cu}^{2+}$ in $\mathrm{CH}_{3} \mathrm{OH} / \mathrm{H}_{2} \mathrm{O}(99: 1 \mathrm{v} / \mathrm{v})$ system at an excitation of $475 \mathrm{~nm}$. As shown in Fig. S4, $\dagger$ the fluorescence spectras with the presence of other metal cations were almost the same as that with the presence of only $\mathrm{Cu}^{2+}$, which also indicated that the detection of $\mathrm{Cu}^{2+}$ would not be affected by the presence of other metal cations.

Fig. 4 showed that as the $\mathrm{Cu}^{2+}$ concentration increased, the fluorescence intensity of the sensor ML decreased gradually. At a $\mathrm{Cu}^{2+}$ concentration of 8 equiv., the fluorescence intensity was approximately zero and the quenching rate was above $90 \%$, indicating that the sensor ML was highly sensitive to $\mathrm{Cu}^{2+}$. The

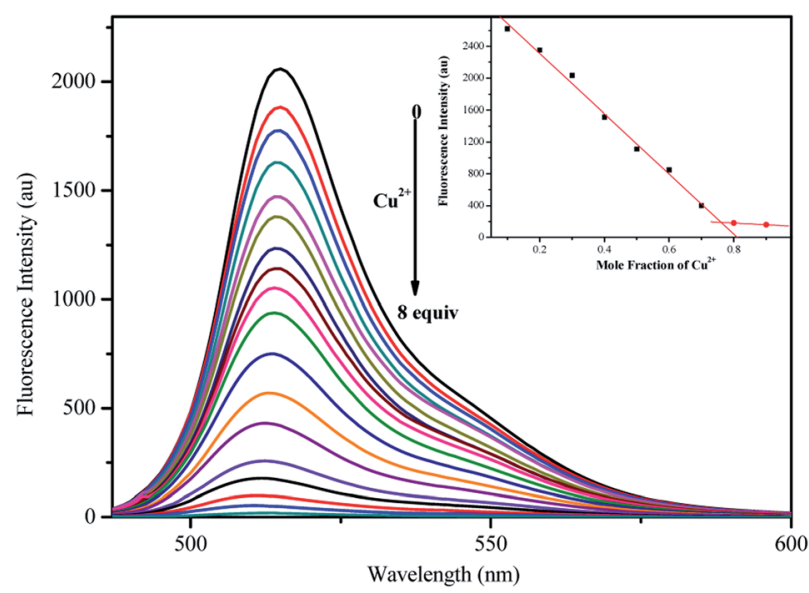

Fig. 4 Fluorescence spectra of $5 \mu \mathrm{M}$ sensor $\mathrm{ML}$ with the addition of various concentrations of $\mathrm{Cu}^{2+}$ in $\mathrm{CH}_{3} \mathrm{OH} / \mathrm{H}_{2} \mathrm{O}(99: 1 \mathrm{v} / \mathrm{v})$ system at an excitation of $475 \mathrm{~nm}$. The inset plots showed that sensor $\mathrm{ML}$ formed a $1: 3$ complex with $\mathrm{Cu}^{2+}$.

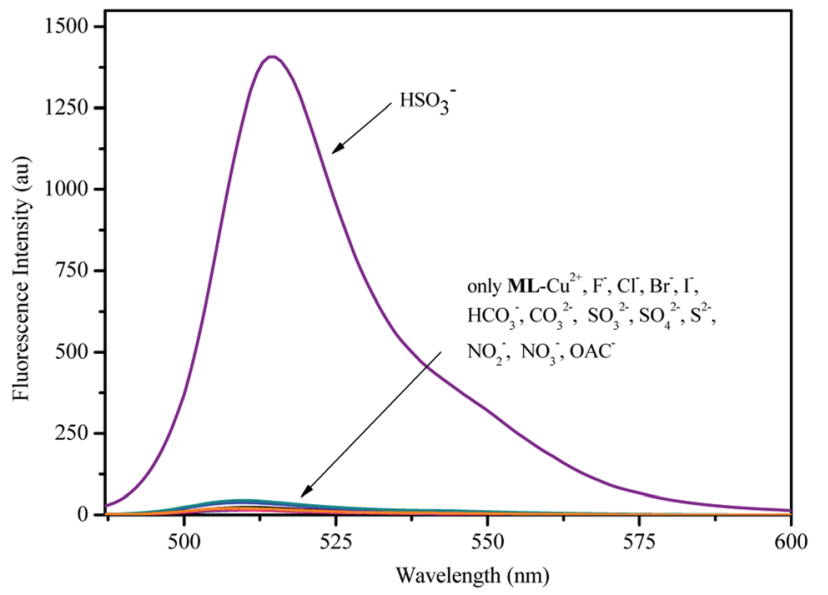

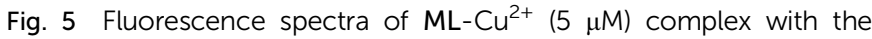
addition of 10 equiv. different anions in $\mathrm{CH}_{3} \mathrm{OH} / \mathrm{H}_{2} \mathrm{O}(99: 1 \mathrm{v} / \mathrm{v})$ system.

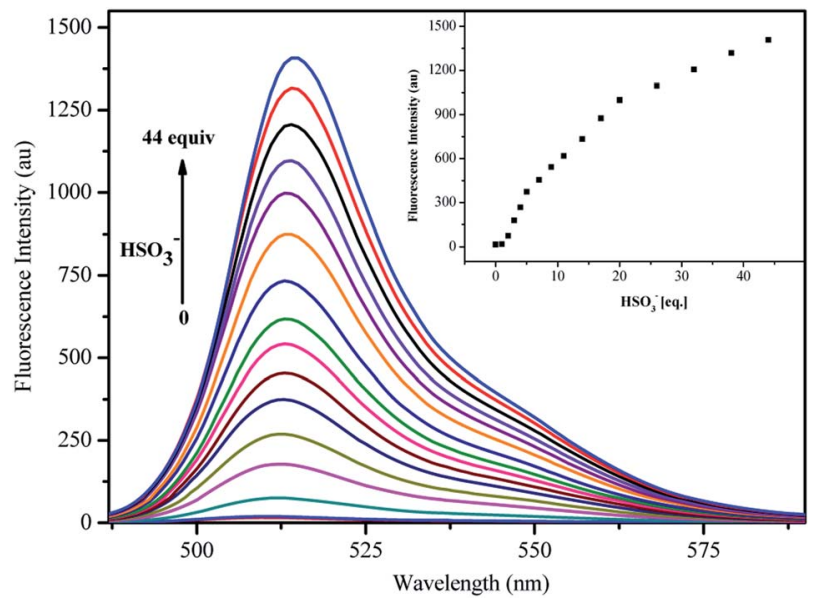

Fig. 6 Fluorescence spectra of $5 \mu \mathrm{M} \mathrm{ML-Cu^{2+ }}$ in the presence of various concentrations of $\mathrm{HSO}_{3}{ }^{-}$in $\mathrm{CH}_{3} \mathrm{OH} / \mathrm{H}_{2} \mathrm{O}(99: 1 \mathrm{v} / \mathrm{v})$ system at an excitation of $475 \mathrm{~nm}$.

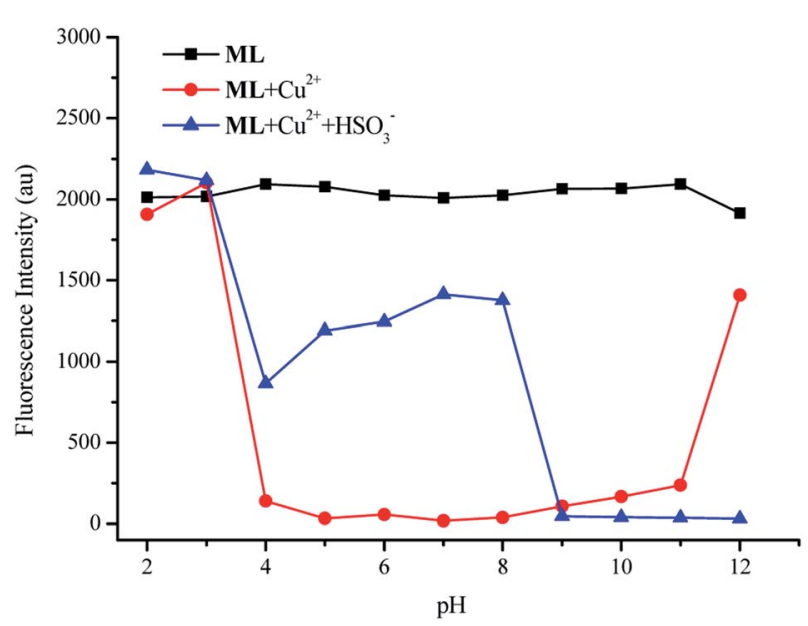

Fig. 7 Changes of the fluorescence intensity of sensor $\mathrm{ML}$ towards $\mathrm{Cu}^{2+}$ (10 equiv.) and $\mathrm{HSO}_{3}^{-}$(10 equiv.) over a wide range of $\mathrm{pH}$ in $\mathrm{CH}_{3} \mathrm{OH} / \mathrm{H}_{2} \mathrm{O}(99: 1 \mathrm{v} / \mathrm{v})$ system at room temperature. 


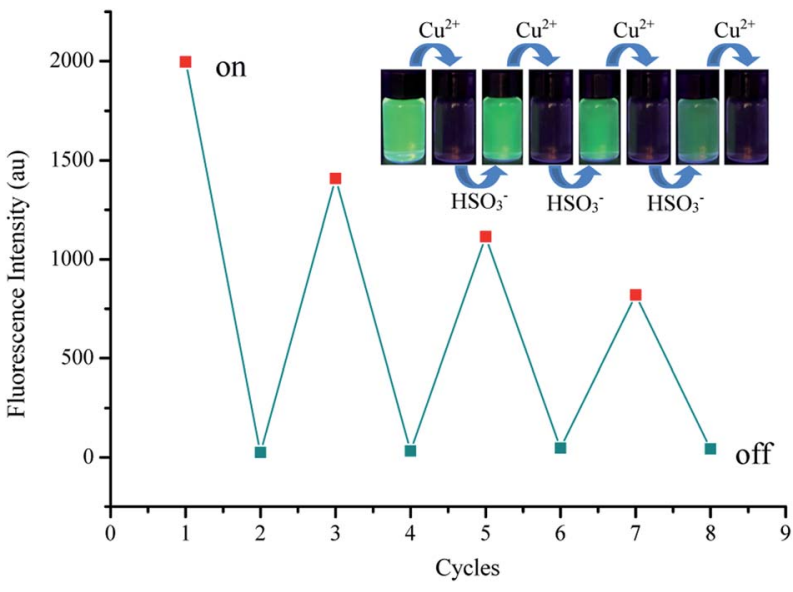

Fig. 8 The sequential recognition of sensor $\mathrm{ML}(10 \mu \mathrm{M})$ upon alternate addition of $\mathrm{Cu}^{2+}$ and $\mathrm{HSO}_{3}{ }^{-}$in $\mathrm{CH}_{3} \mathrm{OH} / \mathrm{H}_{2} \mathrm{O}(99: 1 \mathrm{v} / \mathrm{v})$ system $\left(\lambda_{\text {ex }}=\right.$ $475 \mathrm{~nm})$

binding constant $K_{\mathrm{a}}$ was determined to be $1.70 \times 10^{4} \mathrm{M}^{-1}\left(R^{2}=\right.$ 0.99675 , Fig. S5 $\dagger$ ) and the detection limit was calculated to be $0.36 \mu \mathrm{M}$ by LOD $=3 \sigma / m$ (Fig. S6 $\dagger$ ). The Job curve at the upper right corner showed that the inflection point was observed at a $\mathrm{Cu}^{2+}$ concentration of 0.76 equiv., indicating that the coordination ratio of the sensor $\mathbf{M L}$ and $\mathrm{Cu}^{2+}$ was $1: 3$.

\section{Fluorescence response of $\mathrm{ML}-\mathrm{Cu}^{2+}$ complex towards $\mathrm{HSO}_{3}{ }^{-}$}

The complex formed by the sensor $\mathbf{M L}$ and $\mathrm{Cu}^{2+}$ was used as a new sensor $\mathbf{M L}-\mathrm{Cu}^{2+}$ for sequential recognition of anions. As shown in Fig. 5, the fluorescence intensity was enhanced after the addition of anions containing $\mathrm{HSO}_{3}{ }^{-}$, but remained unchanged after the addition of other anions. The fluorescence was recovered to a large extent after adding $\mathrm{HSO}_{3}{ }^{-}$with a response rate of $70 \%$, indicating that the new sensor could identify $\mathrm{HSO}_{3}{ }^{-}$ specifically. As shown in Fig. S7, $\dagger$ the addition of $\mathrm{HSO}_{3}{ }^{-}$to $\mathbf{M L}-$ $\mathrm{Cu}^{2+}$ containing other anions still resulted in an obvious enhance in the fluorescence response. Thus, the sensor $\mathbf{M L}-\mathrm{Cu}^{2+}$ was not interfered by other anions, and the interference of other sulfurcontaining anions was also excluded, which further indicated that the $\mathrm{ML}-\mathrm{Cu}^{2+}$ had good selectivity to $\mathrm{HSO}_{3}{ }^{-}$.

It could be seen from Fig. 6 that the intensity of the strongest fluorescence emission peak gradually increased with the increase of $\mathrm{HSO}_{3}{ }^{-}$concentration to 44 equiv., after which the intensity remained largely unchanged. Furthermore, the detection limit was $1.4 \mu \mathrm{M}$ according to the formula $\mathrm{LOD}=3 \sigma /$ $m$ (Fig. S8†).

\section{Effect of pH}

Fig. 7 showed that the fluorescence of sensor ML was quenched after the addition of $\mathrm{Cu}^{2+}$ at $\mathrm{pH}=4-11$, and sensor ML could sequentially recognize $\mathrm{Cu}^{2+}$ and $\mathrm{HSO}_{3}{ }^{-}$at $\mathrm{pH}=4-8$. It might be that the disruption of the structure of sensor $\mathrm{ML}$ under strong acid and alkali conditions affected the coordination ability of sensor $\mathrm{ML}$ with ions. Furthermore, $\mathrm{HSO}_{3}{ }^{-}$ and $\mathrm{OH}^{-}$could not coexist in a large amount under alkaline conditions, so sensor $\mathbf{M L}$ had no recognition response to $\mathrm{HSO}_{3}{ }^{-}$at $\mathrm{pH}=9-12$.

\section{Reversibility of sensor $\mathrm{ML}$ for $\mathrm{Cu}^{2+}$ and $\mathrm{HSO}_{3}{ }^{-}$}

The stability of sensor $\mathbf{M L}$ in identifying $\mathrm{Cu}^{2+}$ and $\mathrm{HSO}_{3}{ }^{-}$was discussed with $\mathrm{Cu}^{2+}$ and $\mathrm{HSO}_{3}{ }^{-}$as input signals and fluorescence intensity as output signals. As shown in Fig. 8, the fluorescence intensity quenched by $\mathrm{Cu}^{2+}$ still remained stable after four cycles; the recovery rate of the fluorescence intensity after the first addition of $\mathrm{HSO}_{3}{ }^{-}$was above $70 \%$, and then the three recovery rates gradually decreased. The figure at the upper right corner showed that the sensor ML could be used to sequentially identify $\mathrm{Cu}^{2+}$ and $\mathrm{HSO}_{3}{ }^{-}$in practical applications.

\section{The possible mechanism of sensor $\mathrm{ML}$ for $\mathrm{Cu}^{2+}$ and $\mathrm{HSO}_{3}{ }^{-}$}

The Job curve showed that the coordination ratio of sensor ML to $\mathrm{Cu}^{2+}$ was $1: 3$. The sensor $\mathrm{ML}$ provided three coordination
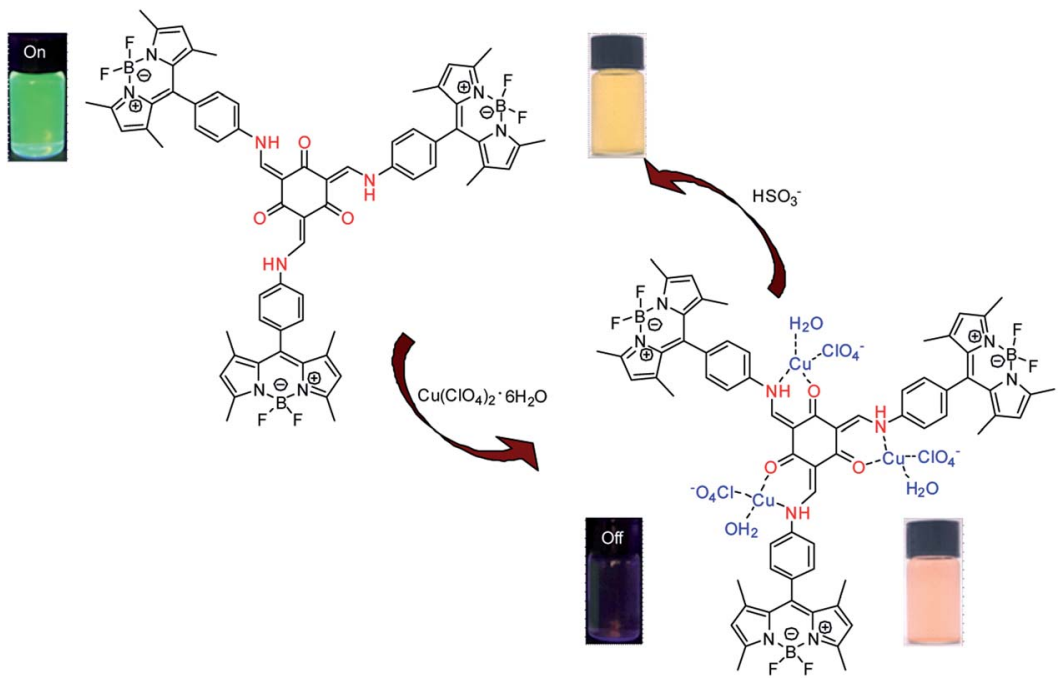

Scheme 2 The possible mechanism of $\mathrm{ML}_{-} \mathrm{Cu}^{2+}$ with $\mathrm{HSO}_{3}{ }^{-}$. 
points through the three $\mathrm{O}$ atoms on the carbonyl group and the three $\mathrm{N}$ atoms at the $-\mathrm{NH}$-position to form a metal copper by 1 : 3 bonding with $\mathrm{Cu}^{2+}$. This sensor ML showed an "on-off-on" fluorescence response to $\mathrm{Cu}^{2+}$ and $\mathrm{HSO}_{3}{ }^{-}$in $\mathrm{CH}_{3} \mathrm{OH} / \mathrm{H}_{2} \mathrm{O}(99: 1$ $\mathrm{v} / \mathrm{v}$ ) system.

In order to better understand the binding mode between sensor $\mathrm{ML}$ and $\mathrm{Cu}^{2+}$, the ${ }^{1} \mathrm{H}$ NMR titration experiments were conducted as showed in Fig. S9. $\dagger$ As the $\mathrm{Cu}^{2+}$ concentration increased, the $\mathrm{N}-\mathrm{H}$ signals gradually disappeared with respect to sensor ML. The broadening of signals could also be affected by coordination. The molecular ion peak (ESI-MS) at 1713.14284 $\left[\right.$ sensor $\mathrm{ML}+3 \mathrm{Cu}^{2+}+3 \mathrm{ClO}_{4}{ }^{-}+3 \mathrm{H}_{2} \mathrm{O} ; \mathrm{m} / \mathrm{z}$ calcd for 1713.16792$]$

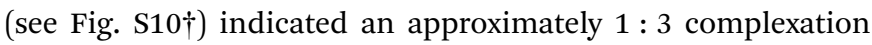
between sensor $\mathbf{M L}$ and $\mathrm{Cu}^{2+}$. Based on the analysis of Job's plot, mass spectrometry and ${ }^{1} \mathrm{H}$ NMR, the possible coordination mode was shown in Scheme 2.

\section{Conclusions}

In this study, sensor ML was successfully synthesized for sequential recognition of $\mathrm{Cu}^{2+}$ and $\mathrm{HSO}_{3}{ }^{-}$. Sensor ML showed an obvious "on-off" fluorescence quenching response toward $\mathrm{Cu}^{2+}$ with a quenching efficiency of above $90 \%$, and the colour of the solution changed from yellow to pink. The $\mathbf{M L}-\mathrm{Cu}^{2+}$ complex could be used to identify $\mathrm{HSO}_{3}{ }^{-}$selectively with a recovery rate of above $70 \%$. Sensor ML showed a $1: 3$ binding stoichiometry to $\mathrm{Cu}^{2+}$ with a complexation constant of $1.70 \times$ $10^{4} \mathrm{M}^{-1}$. The detection limits for $\mathrm{Cu}^{2+}$ and $\mathrm{HSO}_{3}{ }^{-}$were calculated to be $0.36 \mu \mathrm{M}$ and $1.4 \mu \mathrm{M}$, respectively. The stable $\mathrm{pH}$ range of sensor $\mathrm{ML}$ to $\mathrm{Cu}^{2+}$ and $\mathrm{ML}^{-\mathrm{Cu}^{2+}}$ to $\mathrm{HSO}_{3}{ }^{-}$was from 4 to 8.

\section{Conflicts of interest}

There are no conflicts to declare.

\section{Acknowledgements}

We gratefully acknowledge the financial support from the Science Foundation of North University of China (No. 110121).

\section{Notes and references}

1 H. M. Kang, C. B. Fan, H. T. Xu, G. Liu and S. Z. Pu, Tetrahedron, 2018, 74, 4390-4399.

2 H. Wang, B. Fang, L. Zhou, L. Di, K. Lin, U. Kajsa and Z. J. Hu, Org. Biomol. Chem., 2018, 16, 2264-2268.

3 M. A. Cardona, M. Kveder, U. Baisch, M. R. Sensorrt and D. C. Magriet, $R S C$ Adv., 2016, 6, 84712-84721.

4 K. K. Liu, L. N. Zhang, L. N. Zhu, R. Zhang, X. Z. Li and D. M. Kong, Sens. Actuators, B, 2017, 247, 179-187.

5 Z. Y. Zhang, Y. P. Liu and E. J. Wang, Dyes Pigm., 2019, 163, 533-537.

6 H. S. Jung, P. S. Kwon, J. W. Lee, J. I. Kim, C. S. Hong, J. W. Kim, S. Yan, J. Y. Lee, J. H. Lee, T. Joo and J. S. Kim, J. Am. Chem. Soc., 2009, 131, 2008-2012.
7 B. Zhang, Q. P. Diao, P. Ma, X. Liu, D. Q. Song and X. H. Wang, Sens. Actuators, B, 2016, 225, 579-585.

8 H. M. Kang, C. B. Fan, H. T. Xu, G. Liu and S. Z. Pu, Spectrochim. Acta, Part A, 2019, 322-329.

9 S. Erdemir and S. Malkondu, Dyes Pigm., 2019, 163, 330-336.

10 R. Squitti, M. Siotto, M. Arciello and L. Rossi, Metallomics, 2016, 8, 863-873.

11 X. Tian, Z. P. Dong, J. R. Hou, R. Wang and J. T. Ma, J. Lumin., 2014, 145, 459-465.

12 Y. L. Fu, C. B. Fan, G. Liu and S. Z. Pu, Sens. Actuators, B, 2017, 239, 295-303.

13 D. D. Xue, C. H. Zheng, S. Z. Qu, G. M. Liao, C. B. Fan, G. Liu and S. Z. Pu, Luminescence, 2017, 32, 652-660.

14 X. J. Meng, D. L. Cao, Z. Y. Hu, X. H. Han, Z. C. Li, D. Liang and W. B. Ma, Tetrahedron Lett., 2018, 59, 4299-4304.

15 S. L. Li, H. C. Ding, Y. S. Wang, C. B. Fan, G. Liu and S. Z. Pu, RSC Adv., 2019, 9, 6643-6649.

16 J. Wang, J. Liang, X. Liu, X. Han, F. P. Dong, Y. L. Wang, X. Shu, F. R. Huang and H. B. Liu, Spectrochim. Acta, Part A, 2019, 215, 260-265.

17 J. B. Qiu, S. J. Jiang, B. N. Lin, H. Y. Guo and F. F. Yang, Dyes Pigm., 2019, 170, 107590.

18 Z. P. Meng, S. L. Wu, L. H. Zhong, M. Zeng, X. Q. Sun, L. Li and S. F. Zhang, RSC Adv., 2018, 8, 38075-38080.

19 S. L. Guo, G. Liu, C. B. Fan and S. Z. Pu, Sens. Actuators, B, 2018, 266, 603-613.

20 Y. T. Yang, B. Z. Bai, W. Z. Xu, Z. D. Xu, J. C. Zhang and W. Li, Dyes Pigm., 2017, 136, 830-835.

21 J. W. Shi, W. Shu, Y. Tian, Y. L. Wu, J. Jing, R. B. Zhang and X. L. Zhang, RSC Adv., 2019, 9, 22348-22354.

22 H. D. Li, Q. C. Yao, J. L. Fan, C. Hu, F. Xu, J. J. Du, J. Y. Wang and X. J. Peng, Ind. Eng. Chem. Res., 2016, 55, 1477-1483.

23 X. L. Zheng, H. Li, W. Feng, H. C. Xia and Q. H. Song, ACS Omega, 2018, 3, 11831-11837.

24 J. L. Wang, Y. F. Hao, H. Wang, S. X. Yang, H. Y. Tian, B. G. Sun and Y. G. Liu, J. Agric. Food Chem., 2017, 65, 2883-2887.

25 F. Zhou, Y. Sultanbawa, H. Feng, Y. L. Wang, Q. T. Meng, Y. Wang, Z. Q. Zhang and R. Zhang, J. Agric. Food Chem., 2019, 67, 4375-4383.

26 J. Lu, P. Wu, Y. X. Geng and J. C. Wang, RSC Adv., 2018, 8, 33459-33463.

27 J. B. Chao, H. J. Wang, Y. B. Zhang, C. X. Yin, F. J. Huo, J. Y. Sun and M. G. Zhao, New J. Chem., 2018, 42, 3322-3333.

28 D. Don, K. Velmurugan, J. Prabhu, N. Bhuvanesh, A. Thamilselvan and R. Nandhakumar, Spectrochim. Acta, Part A, 2017, 174, 62-69.

29 L. Zou, G. Zhang, M. H. Zhou, X. Xin, S. Chen, X. M. Duan and J. K. Xu, Ind. Eng. Chem. Res., 2019, 58, 9231-9238.

30 X. H. Li, R. Q. Zeng, C. Y. Xie, D. G. Tang, Q. Li, B. G. Zhang and T. Huang, Dyes Pigm., 2019, 165, 128-136.

31 S. Xu, R. R. Tang, Z. Wang, Y. Zhou and R. Yan, Spectrochim. Acta, Part A, 2015, 149, 208-215.

32 X. H. Cheng, H. Z. Jia, J. Feng, J. G. Qin and Z. Li, Sens. Actuators, B, 2013, 184, 274-280.

33 M. G. Choi, J. Hwang, S. Eor and S. K. Chang, Org. Lett., 2010, 12, 5624-5627. 
34 X. Ma, C. X. Liu, Q. L. Shan, G. H. Wei, D. B. Wei and Y. G. Du, Sens. Actuators, B, 2013, 188, 1196-1200.

35 J. Li, Y. Gao, H. R. Guo, X. K. Li, H. Y. Tang, J. Li and Y. Guo, Dyes Pigm., 2019, 163, 285-290.

36 K. Y. Bi, R. Tan, R. T. Hao, L. X. Miao, Y. Q. He, X. H. Wu, J. F. Zhang and R. Xu, Chin. Chem. Lett., 2019, 30, 545-548.

37 X. H. Pan, Y. Zhong, Y. S. Jiang, G. C. Zuo, J. J. Li and W. Dong, Mater. Chem. Phys., 2018, 213, 83-88.

38 Y. Huang, C. F. Li, W. J. Shi, H. Y. Tan, Z. Z. He, L. Y. Zheng, F. G. Liu and J. W. Yan, Talanta, 2019, 198, 390-397.

39 Y. N. Li, L. Yang, M. Q. Du and G. J. Chang, Analyst, 2019, 144, 1260-1264.
40 S. Jantra, P. Butta, P. Jithavech, P. Rojsitthisak, T. Palaga, P. Rashatasakhon, M. Sukwattanasinitt and S. Wacharasindhu, Dyes Pigm., 2019, 162, 189-195.

41 J. H. Ye, J. Xu, H. C. Chen and Y. Bai, RSC Adv., 2014, 4, 6691. 42 Y. Gawale, S. Mangalath, N. Adarsh, J. Joseph, D. Ramaiah and N. Sekar, Dyes Pigm., 2019, 171, 107684.

43 M. Xu, C. X. Yin, F. J. Huo, Y. B. Zhang and J. B. Chao, Sens. Actuators, B, 2014, 204, 18-23.

44 Y. P. Wang, D. L. Qiu, M. N. Li, Y. J. Liu, H. B. Chen and H. M. Li, Spectrochim. Acta, Part A, 2017, 185, 256-262.

45 Y. J. Cheng, R. Wang, S. Wang, X. J. Xi, L. F. Ma and S. Q. Zang, Chem. Commun., 2018, 54, 13563-13566.

46 T. Matsumoto, Y. Urano, T. Shoda, H. Kojima and T. Nagano, Org. Lett., 2007, 9, 3375-3377. 